\title{
Legal Regulation and Policy on the Use of Restraint and Coercive Measures in Health Care Institutions in the Netherlands
}

Citation for published version (APA):

Waddington, L. (2020). Legal Regulation and Policy on the Use of Restraint and Coercive Measures in Health Care Institutions in the Netherlands. In B. McSherry, \& Y. Maker (Eds.), Legal Regulation and Policy on the Use of Restraint and Coercive Measures in Health Care Institutions in the Netherlands (pp. 141-168). Routledge. https://doi.org/10.4324/9780429355219-10

Document status and date:

Published: 14/12/2020

DOI:

10.4324/9780429355219-10

Please check the document version of this publication:

- A submitted manuscript is the version of the article upon submission and before peer-review. There can be important differences between the submitted version and the official published version of record.

People interested in the research are advised to contact the author for the final version of the publication, or visit the DOI to the publisher's website.

- The final author version and the galley proof are versions of the publication after peer review.

- The final published version features the final layout of the paper including the volume, issue and page numbers.

Link to publication

\footnotetext{
General rights rights.

- You may freely distribute the URL identifying the publication in the public portal. please follow below link for the End User Agreement:

www.umlib.nl/taverne-license

Take down policy

If you believe that this document breaches copyright please contact us at:

repository@maastrichtuniversity.nl

providing details and we will investigate your claim.
}

Copyright and moral rights for the publications made accessible in the public portal are retained by the authors and/or other copyright owners and it is a condition of accessing publications that users recognise and abide by the legal requirements associated with these

- Users may download and print one copy of any publication from the public portal for the purpose of private study or research.

- You may not further distribute the material or use it for any profit-making activity or commercial gain

If the publication is distributed under the terms of Article $25 \mathrm{fa}$ of the Dutch Copyright Act, indicated by the "Taverne" license above, 


\title{
7. Legal regulation and policy on the use of restraint and coercive measures in health care institutions in the Netherlands
}

\author{
Lisa Waddington
}

\section{Overview}

Dutch psychiatric hospitals have been engaged in a range of projects to reduce the use of seclusion and others forms of coercive treatment since 1998. Between 2006 and 2012, this goal was supported by Dutch government funding of 35 million euros and involved a nationwide approach coordinated by GGZ Nederland (translated as the Dutch Association of Mental Health and Addiction Care), the country's mental health umbrella organisation (Noorthoorn et al 2016: 1321; Voskes 2015: 34). There was a particular focus on reducing the use of seclusion, because seclusion rates in the Netherlands were above average compared to similar countries, both in terms of number and duration. In contrast, as noted by Voskes (2015: 52), in most European countries chemical restraint (or involuntary or forced medication) is 'the primary coercive measure of choice'. Subsequent evaluations have revealed that the rate of seclusion has reduced somewhat in the Netherlands, although this has been partially accompanied by an increase in the use of involuntary medication. A key factor in allowing for such longitudinal evaluations was mandatory registration of all individual uses of restraint and coercive treatment in all psychiatric institutions. This registration allowed for benchmarking but has also proved problematic from the perspective of protecting the privacy of individuals subject to coercive measures.

This chapter begins by briefly setting out relevant background information about the Dutch (mental) health care system and introducing key terms. The chapter then examines the legal framework in the Netherlands which regulates the use of restraint and coercive measures in psychiatric institutions, as well as institutions housing people with intellectual disabilities and people with psychogeriatric conditions. That legal framework has recently been subject to significant change, with the previous legislation, the Psychiatric Hospitals (Compulsory Admissions) Act (also translated into English as the Compulsory Admissions Act or the Special Admission to Psychiatric Hospitals Act) ceasing to have effect from 1 January 2020, and replaced on that date by two new statutes: the Compulsory Mental Health Care Act and the Care and Compulsion Act, which are intended to be more client-centred. The chapter also examines the registration system which was designed to record each use of restraint, coercion and involuntary treatment in Dutch psychiatric institutions, and the controversies surrounding the system related to patient privacy. Lastly, on the basis of desk research, the chapter identifies factors which seem to have influenced the (reduced) use of coercive measures, and particularly seclusion, in psychiatric institutions in the Netherlands. 


\section{Introduction to the Dutch (mental) health care system and terminology}

This section provides relevant background information, including relating to terminology.

The (mental) health care system in the Netherlands

The Netherlands has a population of approximately 17 million people and, in 2017, spent 10.1 per cent of its gross domestic product on health care (Organisation for Economic Cooperation and Development (OECD) 2019). In comparison, in the same year, Australia spent 9.1 per cent, the United Kingdom spent 9.6 per cent and the United States spent 17.2 per cent of their gross domestic products on health care (OECD 2019). The Dutch health care system is regulated through four main statutes: the Health Insurance Act, the Long-term Care Act, the Social Support Act and the Youth Act. Treatment and care related to the first two statutes account for the vast majority of the health care budget (Netherlands Ministry of Health, Welfare and Sport [Ministrie van Volksgezondheid, Welzijn en Sport] 2016: 3). Under the Health Insurance Act every resident of the Netherlands is obliged to take out insurance covering health care (Netherlands Ministry of Health, Welfare and Sport 2016: 7). The minimum health insurance coverage, which is fairly broad, is determined by the government (Netherlands Ministry of Health, Welfare and Sport 2016). Insurance providers on the market are obliged to accept all individuals, irrespective of their state of health; and the premium charged cannot be based on an individual's state of health or anticipated health needs (Netherlands Ministry of Health, Welfare and Sport 2016: 7). Most insurance providers are cooperative non-profit making organisations (Netherlands Ministry of Health, Welfare and Sport 2016). The minimum package includes extramural mental health care (Netherlands Ministry of Health, Welfare and Sport 2016: 8) and long-term care (up to three years) provided in a mental health institution (Netherlands National Health Care Institute [Zorginstituut Nederland] 2019).

The average cost of such insurance for individuals was 1200 euros in 2016. In addition, individuals must cover the first 385 euros (as of 2016) of the cost of health care themselves per year, although this does not apply to general practitioner consultations and some other forms of treatment (Netherlands Ministry of Health, Welfare and Sport 2016: 10). Individuals who receive mental health care without their consent are also obliged to pay this sum (GGZ Centraal 2019). Lastly, employers must make an income related contribution to the health insurance of each employee. At a macro level, this contribution is similar to the annual premium paid by individuals (GGZ Centraal 2019). All individuals also have the option to take out insurance to cover additional risks, although pre-selection or additional conditions are allowed in such cases. About 90 per cent of insured individuals take out this additional 
risk cover, which includes for example, (partial) reimbursement of the costs of dental treatment, physiotherapy, glasses and contact lenses (Netherlands Ministry of Health, Welfare and Sport 2016: 10). The government covers the cost of insuring children under the age of 18, and people on low incomes receive financial support to help cover the cost of health insurance (Netherlands Ministry of Health, Welfare and Sport 2016: 10).

This approach aims to realise a 'demand driven' system, whereby health insurers contribute to improvements in the health care system, such as shorter waiting lists, less bureaucracy, and more attention to quality. Health insurers can also influence the price charged for health care, and its quality, by negotiating contracts with selected providers (Netherlands Ministry of Health, Welfare and Sport 2016: 4).

The Long-term Care Act is also relevant in the context of certain kinds of mental health care and disability-related care. However, it should be noted that there are complex rules regarding which statute, and therefore which organisation, is responsible for funding mental health care (Netherlands National Health Care Institute [Zorginstituut Nederland] 2017). The Long-term Care Act establishes a mandatory collective health insurance which covers risks which cannot be insured on an individual basis. The Act is based on the principle of solidarity and covers health care needs of people who are regarded as particularly 'vulnerable', including people with chronic mental health problems or an intellectual disability (Netherlands Ministry of Health, Welfare and Sport 2016: 3). The cost of this care is covered from general taxation, although individuals are required to pay a contribution to the cost of their treatment based on their income (Netherlands Ministry of Health, Welfare and Sport 2016: 15). The cost of long-term care provided in a psychiatric or disability-care institution is covered under the Long-term Care Act, where the stay exceeds three years. Stays of shorter duration are covered by the Health Insurance Act (Netherlands National Health Care Institute 2019). However, if an individual has received an official 'indication' (a finding of entitlement to a particular form of treatment) that they require long-term mental health care in an institutionalised setting, the cost of the care is covered by the Long-term Care Act before the three-year period has passed.

In terms of mental health care, the Netherlands has a relatively high number of psychiatric hospital beds, with 139 beds per 100,000 members of the population (World Health Organization 2019).

\section{Terminology}

This chapter refers to different forms of treatment and interventions. The term 'involuntary treatment' is used to refer to any kind of treatment or intervention, such as placing an individual in a seclusion room, which takes places without the individual's consent. Consent 
can be withheld in a number of ways, including refusing to sign a consent form, but also by displaying physical resistance or refusing to agree to an intervention verbally or non-verbally. Under Dutch law, involuntary treatment is treatment which takes place without the consent of the individual and involves treatment which is not foreseen in the individual's care plan. Such treatment may only take place in institutions which have been registered with the Ministry of Health, Welfare and Sport (discussed further below).

The term 'coercion' covers not only involuntary treatment as defined above, but also the situation where a person is pressured to accept a treatment or intervention which they do not wish to receive. This may occur, for example, where an individual is told that they will be physically restrained if they do not accept certain medication, or vice versa, leading them to agree to the intervention which they regard as least bad in the circumstances. However, true consent is not given in such a situation, and such treatment can also be regarded as involuntary (Janssen 2012: Ch 1). Since coercive treatment may involve elements which give the appearance of consent, such as the signing of a consent form or acceptance of treatment without demonstrating physical resistance, it may not be classified as involuntary by health care providers in situations where they are obliged to record all incidents of involuntary treatment. This form of coercion, resulting from placing individuals under pressure to make a certain choice, is not regulated under Dutch law.

'Freedom restricting' measures are interventions which impair an individual's ability to move freely or behave as they would wish to. This term can also be interpreted more strictly only to mean an intervention that restricts a person's freedom to act as they would wish. In that context, freedom restricting measures are a form of coercion. However, if freedom restricting measures are seen as also including measures which restrict a person's freedom to move, they could result either from coercion or a request from an individual. For example, a request from an individual to be placed in a secluded environment which they cannot leave for some time restricts their freedom but is done with their consent. The term seemed to be understood in this broad way in the Argus register (discussed below), since freedom restricting interventions made at the request of the patient also had to be reported to the register.

The term 'restraint' covers any intervention which is used to control a person's actions against their will. It includes the administration of medication primarily intended to control an individual's behaviour rather than to treat a medical condition; the use of mechanical restraint, such as a strap or belt or other device, to control a person's freedom of movement; and the use of physical restraint, involving bodily force to control a person's freedom of movement. For the purposes of this chapter, it also covers 'environmental restraint' which involves controlling or restricting a person's freedom to move outside the immediate area in which they are detained. This occurs, for example, where a person is placed in an isolation or seclusion room against their will. Seclusion and restraint, as described by Janssen (2012: Ch $1,5)$, concern 'interventions with the highest level of force and limitations in which the patient no longer has a choice'. 
In the Netherlands, the focus of legislative protection is on involuntary treatment although, as seen from the definitions given above, there is a broad overlap between involuntary treatment and restraint measures.

\title{
The legal framework regulating the use of involuntary treatment, coercion and restraint in Dutch health care institutions
}

\author{
The Psychiatric Hospitals (Committals) Act (Bopz)
}

The Psychiatric Hospitals (Committals) Act (acronym in Dutch: Bopz), which came into force in 1994, and which was repealed in 2019, regulated forced admissions to psychiatric hospitals. Unlike some countries, in the Netherlands a hospital committal does not automatically mean that a patient can also be subject to involuntary medical or coercive treatment, such as restraint (Pols 2002: 322). The Bopz therefore also regulated the conditions which had to be met for each individual case of involuntary medical treatment or restraint to be lawful. The Act only applied in cases where an individual had been committed (Bopz: Ch III), meaning that individuals who were being treated on a voluntary basis had in principle less rights when it came to the use of coercion (Arends 2004: 826f; Arends 2010: 95; Arends 2015: 222). The Bopz also only applied to closed institutions, which must be licensed by the Ministry of Health, Welfare and Sport. The use of restraint in other settings, such as within the community, is not regulated to the same degree (Arends 2004: 828), although coercive treatment outside of psychiatric institutions is addressed in the Medical Treatment Agreements Act (acronym in Dutch: WGBO). This allows for compulsory treatment of 'incompetent' patients to prevent serious damage to health.

In spite of its name, the Bopz also regulated committals and involuntary medical or coercive treatment in institutions housing people with intellectual disabilities and people with dementia and similar conditions. However, this broad scope was not regarded as unproblematic, with the second evaluation of the Bopz finding that the legislation, which was originally designed to address the situation of psychiatric patients, provided little protection for patients in psychogeriatric settings or for patients with an intellectual disability and did not provide an appropriate legal framework (Frederiks 2015: 226; Frederiks and Blankman 2013: 346; Arends 2010: 95; Arends 2004: 821). Furthermore, the third evaluation of the Bopz found that the law was too complicated and no longer reflected current views on admission policies in mental health care (Broer, Koetsier and Mulder 2014: 247; Arends 2015; Ploem and Gevers 2015: 206; Arends 2010: 95). 
As of 1 January 2020, the Bopz has been replaced by two separate acts covering the mental health sector, and treatment of people with an intellectual disability or a psychogeriatric condition respectively, although arguments have also been made in favour of a single law regulating the use of coercion in both sectors (Frederiks 2015: 230; Ploem and Gevers 2015: 210-11; Arends 2010: 103). The two new statutes that came into effect in 2020, the Compulsory Mental Health Care Act (acronym in Dutch: Wvggz) and the Care and Compulsion (Psychogeriatric and Intellectually Disabled Patients) Act (acronym in Dutch: Wzd) are intended to be more patient- or client-centred than the Bopz and, while the Bopz was regarded as an 'admissions' or 'committal' law, the new laws are regarded as 'care' or 'treatment' laws (Broer, Koetsier and Mulder 2014: 240; Frederick and Steen 2018: 157). However, the new laws continue to allow the use of involuntary treatment and restraint in certain situations and, unlike the Bopz, are intended to also regulate some forms of compulsory treatment in the community (Frederick and Steen 2018).

Under the Bopz, involuntary treatment or restraint was only allowed in order to prevent a situation of danger, or where the involuntary treatment was the only means of treating an individual's condition within a reasonable period of time (Bopz: Art. 38c(1) (a) and (b)). There must have been no other less intrusive measure available, with the Act referring to the treatment being 'absolutely necessary' (Bopz: Art. 38c(1) (b); Verlinde et al 2014: 644-45). The Bopz defined danger both from the perspective of the individual (the patient) and from the perspective of others. Danger existed for the individual if there was a risk of suicide or harm to oneself; harm to the individual's environment, for example, serious disturbances in the community; serious neglect to oneself; or causing so much annoyance to others that there was a risk that this would lead others to respond aggressively (Bopz: Art. 1(f), 1(a-d)). Danger existed for others if there was a risk that the individual would cause serious harm or kill someone else; if the individual posed a risk to the mental health of others; or if the individual seriously neglected another person who was dependent on his/her care (Bopz: Art. 1(f), 2(a-c)). A last form of danger listed in the former Act related to a general threat to the safety of other people or property (Bopz: Art. 1(f)3). In all cases the danger was required to be related to the individuals' psychiatric, intellectual or memory 'disorder'.

The Bopz distinguished between two forms of involuntary treatment: 'means and measures' and other forms of coercive treatment. Means and measures ('middelen en maatregelen') were forms of coercive treatment, including restraint, which could be used in an emergency situation, where the situation leading to the use of the coercive treatment was not addressed in the patient's treatment plan (Bopz: Article 39; Bopz Decision Means and Measures). They could only be used if no less intrusive measures were available to prevent danger, and for a maximum of 7 days, as per the delegated legislation Bopz Decision Means and Measures (Article 3) issued by the Minister of Justice. These 'means and measures' could also never be used as a form of punishment. In addition to allowing the forced administration of fluids or food (Bopz Decision Means and Measures: Article 2(e)), this delegated legislation identified four forms of interventions (Article 2(a-d)) which could be used on a short-term basis in an emergency situation: 
- Isolation ('afzondering'), whereby the patient was placed in a room which was specially designed for isolation. The door was locked.

- Seclusion ('separatie'), whereby the patient was placed in a room which was specially designed for seclusion. The room was required to be officially approved by the Ministry of Health, Welfare and Sport for the use of seclusion, and was more sober (had less facilities) than the room used for isolation. Seclusion was only allowed in psychiatric hospitals, and not in the elderly or disabled care sector.

- Mechanical or physical restraint ('fixatie'), whereby the patient's ability to move was restricted.

- Medication, whereby the patient was given medicine. This related to medication given without the consent of the patient.

If the health care provider believed that the 'means and measures' were still needed after 7 days, because a situation of danger was ongoing, the measures were required to be incorporated in the patient's treatment or care plan and needed to be discussed with the patient and/or their representative as far as possible. Coercive treatment included within a treatment plan must have been intended to have a therapeutic effect. For example, in the case of psychiatric patients, coercive treatment (such as the forcible administration of medication) must have been the only available means of removing the danger resulting from the psychiatric condition within a reasonable period of time (Bopz: Article 38c(1)(a)). In such cases, the maximum duration of the treatment was three months, although this period could be extended under certain conditions and was subject to regular review (Bopz: Article $38 \mathrm{c}(2))$.

Some of the measures identified above could also be foreseen in a patient's treatment plan, which the patient had consented to. If the treatment was foreseen in the plan in specific circumstances, and only administered in those circumstances, the treatment was not regarded as involuntary, unless the patient withdrew consent. The Bopz also allowed for a patient who was committed to draw up a self-binding declaration, whereby he or she gave a health care provider permission to carry out treatment in the future, even if at the moment the treatment was given the patient objected (Bopz: Articles 34a-34p). This was regarded as offering patients the possibility to participate in decision-making and allowed for the patient's wishes to be respected. However, it seems that this tool was hardly ever used (Blankman and Vermariën 2015: 32). A patient could also choose to enter a special care unit/room, which is a unit which is more comfortably furnished than an isolation or seclusion room and which the patient could request to leave at any time. This too did not amount to restraint. 
Where the patient was classified as 'mentally incompetent' ('wilsonbekwaam'), the health care provider was required to consult the patient's representative, such as a close family member, when deciding whether to apply involuntary treatment. If the representative consented, but the patient did not, this also amounted to involuntary treatment, and the conditions set out in the Bopz were still required to be met.

A number of controls or restrictions were imposed on the use of coercive treatment under the Bopz. As noted above, involuntary treatment, including restraint, was only allowed on the basis of the Bopz in institutions which had been licensed to carry out such measures by the Dutch Ministry of Health, Welfare and Sport, and which were registered as such. Under the Bopz coercive treatment could only be used in the case of patients who had been admitted to a health care institution against their will. This occured either through a detention order ('inbewaringstelling') or court order ('rechterlijke machtiging') or through being admitted under Article 60 of the Bopz, meaning that they were admitted without their consent, but also without showing any sign of resistance (Arends 2004: 823). This last procedure was reserved for psychogeriatric patients and people with an intellectual disability. The number of detention orders and, in particular, court orders leading to involuntary admission under the Bopz increased significantly between 2003 and 2013. The total number of committals in 2003 was 14,294, while in 2013 this had risen to 22,866. Broer, Koetsier and Mulder (2014: 242-43) have identified a number of reasons for this increase.

The use of involuntary treatment had to cease once the goal has been achieved - namely the removal of the danger or the improvement in the patient's health. All institutions which provide coercive treatment must have a protocol identifying the kind of treatment which can be provided and implement appropriate ongoing training for staff (Dutch Association of Psychiatry 2008). However, the Bopz did not explicitly identify the party which was competent to administer coercive treatment, although certain forms of treatment, such as administering an injection, could only be provided by registered health care professionals. The use of coercive measures had to be evaluated after the fact and patients had to be able to complain to a complaints committee about their treatment.

The Dutch Health Care Inspectorate had the task of monitoring institutions registered under the Bopz, including with regard to their use of involuntary medical treatment and restraint. The use of involuntary treatment, including its termination, was required to be reported to the Health Care Inspectorate (Bopz: Article 38c(5)), along with a number of other measures, such as the refusal to grant a patient's request for a transfer to another institution (Bopz: Article 43(3)), or the discharge from the institution of a patient who was committed (Bopz: Article 58(3)). The patient could complain about (involuntary) treatment, coercion and restraint to the board of the institution providing the treatment, which then had to appoint a commission to consider the complaint (Bopz: Article 41). It was also possible for the patient to ask the Health Care Inspectorate to take legal action (Bopz: Article 41(a)) or initiate legal action him or herself (Bopz: Article 41(a)5; Steinert, Noorthoorn and Mulder 2014: 2). 
In spite of these safeguards under the Bopz, a 2015 report (Blankman and Vermariën 2015) which examined inter alia the compatibility of the Bopz with the United Nations (UN) Convention on the Rights of Persons with Disabilities (CRPD), found that the law lacked a provision requiring respect for the will and preferences of the patient, did not regulate who was competent to establish that a patient was 'mentally incompetent', or the criteria to be used in making this assessment. This was particularly significant because only patients regarded as 'mentally incompetent' ('wilsonbekwaamheid') could be subject to coercive treatment and restraint (Blankman and Vermariën 2015: 32).

As noted above, as of 1 January 2020 the Bopz was replaced by the Compulsory Mental Health Care Act (Wvggz) and the Care and Compulsion (Psychogeriatric and Intellectually Disabled Patients) Act (Wzd). These are examined further below.

\section{The Compulsory Mental Health Care Act (Wvggz)}

Under the Wvggz, patients have a right to indicate what care and treatment they prefer. However, unlike the Bopz, the Wvggz does not actually refer to 'patients', but rather 'the person concerned' or 'betrokkene'. Article 2(1) of the Wvggz identifies the starting points of the law, which includes the wishes and preferences of the concerned individual. Article 5(5) allows for the individual, with or without family members, to draw up their own care plan, and Article 5(12)(4) refers to the need to take account of the wishes and preferences of the individual in drawing up a plan ('zorgkaart').

Under the Wvggz, unlike the Bopz, the will and preferences of the patient are of central importance (Blankman and Vermariën 2015: 33). Involuntary treatment and restraint will only be allowed in extreme situations and as a last resort (Broer, Koetsier and Mulder 2014: 241). However, such measures can be applied if a patient's behaviour is the result of a psychiatric condition, leads to a serious disadvantage ('ernstig nadeel') for the individual or others, and the involuntary treatment or restraint is the only way to remove the serious disadvantage. The latter requirement means that consensual treatment must not be possible, no less intrusive treatment is possible and the treatment is proportionate and effective (Wvggz: Articles 2:1(2) and (3)). The new term 'serious disadvantage' (Wvggz: Article 1:1(2)) has largely the same meaning as 'danger' under the Bopz and is not intended to allow for coercion in a broader range of situations (Ploem and Gevers 2015: 205). However Broer, Koetsier and Mulder (2014: 245) have argued that the requirement, as set out in the law when it was at draft stage, is possibly 'lighter' (as in easier to satisfy) than the 'danger' criterion under the Bopz. Psychiatric care providers which provide involuntary treatment under the Wvggz must also be licensed, as was the case under the Bopz. 
The Wvggz allows for more possibilities for involuntary treatment and restraint than the Bopz. Possible involuntary treatment and coercive measures include restrictions on movement, seclusion, observation, checking for the presence of behaviour influencing substances, requiring the patient to do or not do something, restricting the patient's use of communication tools, administration of involuntary medication or involuntary therapeutic treatment (Wvggz: Article 3:2). The Wvggz foresees a number of procedures for authorising involuntary treatment and restraint, the most important of which are a court-issued care authorisation or a short-term crisis measure, which is approved by the local mayor (Wvggz: Article 3:1). If there is not a crisis which presents a risk of immediate danger, involuntary treatment can only take place if it has been provided for via a care authorisation order approved by a judge (Wvggz: Ch 6). In an emergency situation, where there is no time to apply and wait for a court issued care authorisation, the local mayor can allow crisis measures to be taken (Wvggz: $\mathrm{Ch}$ 7). This procedure also existed under the Bopz, when it was known as a detention order. However, the crisis measure under the Wvggz is broader than the detention order, because it can regulate all forms of involuntary treatment and restraint, and not only a forced admission or committal. During the procedure, which has an imposed maximum time of 18 hours (Wvggz: Article 7(3)(2)), involuntary treatment can be administered. Unlike the Bopz, the Wvggz will also apply to some elements of ambulant care provided in the community (Wvggz: Article 5:14).

A study has concluded that the Wvggz complies with the requirements of the CRPD to a greater extent than the Bopz, although there remain some issues of concern (Blankman and Vermariën 2015). Blankman and Vermariën (2015: 33), in their study on the conformity of relevant Dutch law with the CRPD, did not find that Article 12 of the CRPD required States Parties to abolish all forms of adult guardianship that partially or wholly affect the legal capacity of a person with a disability. They recognised that the UN Committee on the Rights of Persons with Disabilities took this position on the meaning of Article 12 in its General Comment No 1, but noted 'convincing evidence supporting the correctness of this view could not be found'. Instead Blankman and Vermariën (2015: 33) found a need for a general provision that 'should apply in all care situations, where there may be a person with a handicap lacking the mental capacity to decide for himself and where a supporting person or representative may be needed'.

The Netherlands has submitted a number of declarations when ratifying the CRPD which, in essence, declare that the Dutch approach to regulating and using coercion in psychiatric settings are compatible with Articles 12 and 14 of the CRPD (Welie and Widdershoven 2018: 8). The Dutch Declaration on Article 14 states 'the Kingdom of the Netherlands declares its understanding that the Convention allows for compulsory care or treatment of persons, including measures to treat mental illnesses, when circumstances render treatment of this kind necessary as a last resort, and the treatment is subject to legal safeguards'. However, some authors have argued that Dutch regulations, set out in both the Bopz and its replacements Wvggz and Wzd, are not in line with the 'UN's view' of Articles 12 and 14 of the CRPD (Welie and Widdershoven 2018: 9-11). 
As noted above, the will and preferences of the patient are of central importance under the Wvggz. In addition, the law defines the concept of 'mental incompetence' ('wilsonbekwaamheid') and, except in the case of a court authorisation, a patient's representative can only take decisions once this has been legally established (Blankman and Vermariën 2015: 33). However, the Wvggz (Article 1(3)(7)) does not provide for clear criteria according to which the representative should act, only indicating that they should act in good conscience and must involve the 'incompetent' person in decisions as far as possible. Specific issues regarding involuntary treatment, coercion or restraint were not identified as problematic with regard to the Wvggz and its compliance with the CRPD in the study by Blankman and Vermariën (2015).

\section{The Care and Compulsion (Psychogeriatric and Intellectually Disabled Patients) Act} $(\mathrm{Wzd})$

The second new statute, the Wzd, regulates the treatment of people with an intellectual disability or a psychogeriatric condition who a qualified doctor has identified as needing professional care in order to prevent a 'serious disadvantage' and who have an 'indication' for long-term care under the Long-term Care Act. The term 'serious disadvantage' has the same meaning as under the Wvggz (Wzd: Article 1(2)). The basic assumption underlying this law is 'no, unless' - meaning that coercive measures are not normally appropriate in the care of people with disabilities and elderly people, and that dangerous situations should be addressed through voluntary treatment as far as possible. Treatment is to be given in line with a care plan which has been drawn up with the individual (referred to as a 'client' in the law), or his/her representative where the client is 'mentally incompetent' (Wzd: Ch 2). The competence of a representative to take decisions on behalf of the client is regulated in Article 3 of the Wzd. Blankman and Vermariën (2015: 34) found that this did not breach the requirements of the CRPD, since the affected individual or his/her representative can appeal against a decision of 'mental incompetence' and a totally random decision could not be made. The same study found that the Wzd provides for the wishes and preferences of the client to be taken into account, although more weight could still be given to these (Blankman and Vermariën 2015: 35). In contrast, some academics have argued that the law suggests that once a legal representative has been appointed, that representative can take decisions on behalf of the affected individual, without first checking whether they are competent to take the decision him or herself, which is contrary to the CRPD. It has accordingly been argued that the law on this point should be clarified, in order to avoid misunderstandings (Frederick and Steen 2018: 163).

Involuntary treatment, coercion and restraint can be used under the Wzd where no other means of removing a dangerous situation exists. Article 2(1) of the Wzd provides a list of permissible involuntary treatment. Such treatment can then be provided for in the care plan subject to certain requirements. These requirements involve the client's behaviour creating a 
situation of 'serious disadvantage' where this is due to a psychogeriatric condition or intellectual disability; the involuntary treatment is needed to prevent (further) 'serious disadvantage'; the involuntary treatment is a suitable and proportionate means to achieve this aim; and no less intrusive measure is possible. Treatment is also subject to safeguards, including approval by another medical specialist (Wzd: Article 10). As with the Wvggz, the Wzd (Article 10) can potentially apply to involuntary treatment and restraint used in ambulant care.

Having introduced the Dutch legal framework governing the use of involuntary treatment, including restraint, in psychiatric and some other health care institutions, this chapter will now focus in more detail on one particular requirement of the law: namely the obligation to report instances of involuntary treatment and restraint to a specialised register, which can be used for benchmarking and evaluation, as well as the monitoring role of the Health Care Inspectorate more generally.

\section{The Health Care Inspectorate and the Argus register: Hopes, achievements and controversies}

\section{Overview of the tasks of the Health Care Inspectorate}

The Health Care Inspectorate is responsible for supervising and monitoring the quality and safety of public health services on behalf of the government. While monitoring and supervision of health care by the state has a long history in the Netherlands, dating back to the nineteenth century, it was only in 1957 that the tasks of monitoring and supervising public health generally, and with regard to psychiatric institutions, were merged (Robbe, Bal and Grol 2002: Ch 2). The Inspectorate's key tasks are outlined in the Public Health Act (Gezondheidswet) and involve studying public health in general and its determining factors, and supervising compliance with legal provisions in the field of public health (Public Health Act: Article 36(1)(a) and (b); Hout et al 2010; Ketelaars 2011: 2-3). These statutory tasks were only formally elaborated in 1998. Prior to this a more general provision identified the tasks of the Inspectorate, but this was deemed to leave too much room for confusion and dispute (Legemaate 2001: 140).

The Inspectorate is only responsible for the supervision of laws where this power is given to it explicitly, and at present it has a supervisory role with regard to approximately twenty-five statutes (Hubben 2012: 97; Health Care Inspectorate [Inspectie voor de Gezondsheidszorg] 2016: 15). In October 2017 the Health Care Inspectorate merged with the Inspectorate for Youth Care and is now formally known as the Inspectorate for Healthcare and Youth (the Inspectorate) (acronym in Dutch: IGJ). The Inspectorate falls under the Ministry of Health, 
Welfare and Sport, but acts in a wholly independent and impartial manner (Health Care Inspectorate 2016: 18). The rest of this chapter exclusively refers to the health-related tasks of the Inspectorate.

The starting point for the Inspectorate's supervision is the assumption that health care providers are intrinsically motivated to provide good health care (Robbe, Bal and Grol 2002: 27), whilst recognising that problems can nevertheless occur (Health Care Inspectorate 2016: 22). In principle, the Inspectorate should not intervene more than necessary and adopts an approach of 'responsive regulation' (Robbe, Bal and Grol 2002: 41). Health care providers are expected to supervise themselves (Robbe, Bal and Grol 2002: 26), although Legemaate has noted that this is not uncontroversial (2001: 141). The Inspectorate accordingly only provides supervision at a distance ('toezicht op toezicht' or 'supervision of supervision'). The Inspectorate should identify problematic issues and have a general overview of developments, but supervision does not mean that every unauthorised or improper incident is sanctioned by the Inspectorate (Robbe, Bal and Grol 2002: 29). Instead, the Inspectorate should support the responsible institution to find a solution where necessary (Legemaate 2001: 142). As part of its supervisory task, the Inspectorate collects data related to various aspects of health care and analyses trends with a view to raising issues of concern with stakeholders (Health Care Inspectorate 2016: 25). Indicators can also be used as a 'steering instrument', directing attention and policy towards a particular field or risk, and to monitor progress (Health Care Inspectorate 2016: 30). While Robbe, Bal and Grol (2002: 46) identify a number of negative consequences associated with the use of indicators, they conclude that the Inspectorate has no option but to use them as part of their 'risk based monitoring'. As of the 1990s, the market has played an increasingly important role in the provision of health care in the Netherlands, and this has led to a growth in the importance of supervision (Robbe, Bal and Grol 2002: 21).

In cases where the Inspectorate decides to intervene, its actions must be proportionate and based on the scope, risk and seriousness of the problem identified (Health Care Inspectorate 2016: 23). The Inspectorate also aims to act in a transparent way (Robbe, Bal and Grol 2002: 22) and take action which is appropriate in light of the stage of development of the health care provider (Health Care Inspectorate 2016: 23). The Inspectorate uses four kinds of interventions, which vary on a scale from 'light' to 'heavy' (Health Care Inspectorate 2016: 23). These actions, as identified in the Inspectorate's current Multi-year Plan (Health Care Inspectorate 2016: 23; Robbe, Bal and Grol 2002: 27), are:

1. Stimulation/encouragement. These measures can involve campaigns, circular letters, journal articles, reports, motivation, or rewards.

2. Corrective measures. These measures can involve supervised improvement plans or intensified supervision, for example, in the form of additional and unannounced visits. 
3. Administrative measures. These can involve a number of measures provided for under administrative law, including a closure order, the withdrawal of a license, mandatory introduction and compliance with an improvement plan, ordering a particular action, or a fine. Between 2002 and 2011 the number of administrative measures taken by the Inspectorate increased and some measures were introduced for the first time (Robbe, Bal and Grol 2002: 39).

4. Disciplinary or criminal law measures. The Inspectorate can submit a complaint about a health care provider to the recognised disciplinary bodies operating in the health care sector, and these can impose disciplinary measures. The Inspectorate can also refer cases to the public prosecutor.

As noted above, the Inspectorate's supervisory tasks include supervision of compulsory admissions to health care institutions as well as incidents of involuntary treatment, including use of restraint under the Bopz (now repealed). The Inspectorate also has a supervisory role under the Wvggz and Wzd. As with other Inspectorate supervision, this involves ex ante supervision, also known as risk oversight or 'phased supervision' (Hout et al 2010: 350; Robbe, Bal and Grol 2002: 25), as well as ex post supervision or incident oversight. Those incidents can be reported to the Inspectorate by citizens, but, in principle, must be reported to the Inspectorate by the responsible health care institution. Specifically, each coercive incidence must be reported to the Inspectorate, and this information has to be related to the number of involuntary admissions (Janssen 2012: Ch 2). However, research has suggested that the accuracy of reporting and recording has been unreliable, at least in the past (Janssen 2012: Ch 2).

\section{Establishment of the Argus register}

In 2006 a first attempt was made to collect data on a structural basis on the use of involuntary treatment and restraint in institutions falling under the Bopz (Noorthoorn et al 2016: 1321). Prior to this it had been argued, in the context of patients in psychogeriatric care settings, that 'there is hardly any transparency on the use of restraints, and therefore no protection in this respect' (Arends 2004: 827). Consequently a key factor in setting up what became the Argus register was that, given the absence of complete and reliable data, it was difficult to identify trends and developments in the use of coercion in mental health institutions (Voskes 2015: 19 and 35). The data that was being collected by the Health Care Inspectorate was insufficient for this purpose (Noorthoorn et al 2016: 1321; Janssen 2012: Ch 2), with nearly half of coercive measures not being reported to the Inspectorate (Noorthoorn et al 2015: 1858), and data not being recorded in a standard manner to the extent that it was being recorded at all (GGZ Nederland 2012: 9). This led one academic to conclude that 'the registration of data for a legal purpose was unfit for interpretation of trends or developments at a ward or hospital 
level' (Janssen 2012). A national database, which could allow for benchmarking and identification of changes and trends, was important in light of the goal of reducing seclusion in Dutch hospitals by at least $10 \%$ per year. A further factor prompting the establishment of the register was the possibility it would induce institutions to improve quality and demonstrate responsibility (GGZ Nederland 2012: 8).

In 2006, five psychiatric hospitals in cooperation with GGZ Nederland and the Inspectorate set up the Argus register to record instances of involuntary treatment and restraint in a standard manner. Participation was initially voluntary but, in 2012, participation became mandatory for all Bopz licensed mental health care institutions as a result of an amendment to the Bopz (Mann-Poll et al 2018: 741; GGZ Nederland 2012: 9-10). Registration of data was required under Article 57 of the Bopz. By 2014 all 87 psychiatric hospitals in the Netherlands and psychiatric wards in general hospitals with involuntary admissions reported to the Argus register (Noorthoorn et al 2016: 1323). However, for reasons of privacy, and after never having started substantially, from 2016 the collection of data through the register ceased altogether (Noorthoorn 2019). Institutions providing psychogeriatric care and care to people with intellectual disabilities were never obliged to report to the Argus register.

The Argus register was intended to record all 'freedom restricting' measures ('vrijheidsbeperkende interventies') imposed on patients and became the largest database recording the use of such measures in Europe (Janssen et al 2011: 433). The following six types of interventions had to be reported:

1. Seclusion, which involved placing a patient in a locked room specially designed for seclusion. The room was required to be officially approved by the Ministry of Health, Welfare and Sport for the use of seclusion, and had minimal facilities;

2. Isolation, which involved placing the patient in a locked low stimulus room. The room had a bed, table, chair, cupboard and sanitary facilities;

3. Mechanical or physical restraint, which could either involve mechanical devices, such as belts or straps, or physically restraining a person;

4. Parenteral medication, which was defined as medication administered intramuscularly or intravenously, where the patient displayed physical resistance. Other forms of medication did not have to be recorded, because, in the view of GGZ Nederland, there could be a lack of certainty as to when medication was forced in other circumstances (GGZ Nederland 2012: 24). There is however a separate medication register which institutions are obliged to maintain; 
5. Forced hydration and/or nutrition which was administered parenterally or through the mouth, where the patient displayed physical resistance; and

6. Other freedom restricting measures, such as a mandatory stay in the patient's room (Noorthoorn et al 2016: 1322; GGZ Nederland 2012: 19-20; Janssen et al 2011: 430; Janssen et al 2014: 10; Voskes 2015: 36-37).

These definitions of coercive measures are in line with international definitions (Janssen 2012: Ch 9), and this has facilitated comparisons between hospitals and countries (Janssen 2012: Ch 9). For each intervention, the date, start time, and, except for forced medication, end time, had to be recorded (GGZ Nederland 2012: 21; Janssen et al 2011: 430). The patient's level of resistance was also recorded: at own request, no clear resistance, or clear verbal or physical resistance (Noorthorrn et al 2016: 1322; GGZ Nederland 2012: 7; Health Care Inspectorate 2015: 12). In 2012, 52.3 per cent of seclusion incidents involved patients who displayed resistance; 39 per cent involved no resistance, and 8.6 per cent were made at the patient's own request. The relevant figures for isolation were 37.3 per cent (resistance), 53.6 per cent (no resistance) and 10.1 per cent (own request); and for mechanical or physical restraint: 23.5 per cent (resistance), 67.6 per cent (no resistance) and 8.8 per cent (own request) (Voskes 2015: 39).

An intervention occurred at the patient's own request where the initiative for the intervention came from the patient (Janssen et al 2014: 10). A patient displayed no resistance if he or she agreed to an intervention proposed by a health care professional or displayed no visible resistance when the intervention was imposed (Janssen et al 2014: 10). A patient displayed resistance when the initiative for the intervention was taken by a health care professional and the patient visibly resisted the intervention physically, verbally or through non-verbal means (Janssen et al 2014: 10). In the latter two instances coercion was involved within the framework of Articles 38 or 39 of the Bopz (Janssen et al 2014: 10), and the relevant statutory provisions and requirements were applicable. It was not necessary to report an intervention at the request of a patient in the case of parenteral medication, administration of fluids or food, or 'other freedom restricting measures'. However, all cases of seclusion, isolation and restraint had to be reported, even if made at the patient's request, and other forms of freedom restricting intervention had to be reported if the initiative for the action came from the health care provider (GGZ Nederland 2012: 19-20). Data regarding the use of consensual freedom restricting measures was collected in order to obtain a full picture of daily practices in mental health care institutions, and to facilitate full reporting by health care professionals, who were then aware that all freedom restricting measures had to be reported (Noorthoorn 2019).

The data to be registered through Argus was regarded as the minimum data set; institutions were free to collect more detailed data and data concerning other interventions (GGZ Nederland 2012: 24). The legal status of the patient was not determinative for whether 
information should be reported or not (GGZ Nederland 2012: 24), although it was relevant for determining whether interventions could be made without the patient's consent. Institutions had some degree of freedom to decide how to collect the data, and could, for example, collect the information in the electronic patient dossier, use separate software or collect the information in paper format before submitting it digitally (GGZ Nederland 2012: $25)$. The reporting institutions were responsible for ensuring the accuracy of the data submitted, although the Inspectorate could perform random inspections. Some concerns regarding accuracy of the data on seclusion were raised (Noorthoorn et al 2015: 1866), although it has been argued that the reliability of Argus data was 'moderate to good' in the past (Janssen 2012: Ch 9). This argument was made before the controversies surrounding data protection and the subsequent cessation of registration by institutions (see below for further information).

In 2012 GGZ Nederland published guidance and instructions for institutions obliged to report to the Argus register and noted a number of goals and benefits of the register: improving the quality of care, learning from one's own experience, acting responsibly, and providing the basis for better academic research (GGZ Nederland 2012: 5). This guidance included a number of quotes from health care workers or managers in psychiatric institutions which were already registering data. The quotes indicate that reporting to the Argus register facilitated better internal evaluation, reflection on how to reduce the use of coercion, and was an important tool for management in identifying trends and changes (GGZ Nederland 2012: 13-14). This also reflected the view of GGZ Nederland, which noted that, by linking Argus data with individual patient records, institutions could reveal the extent to which specific individuals were exposed to coercive treatment. The data could also help institutions to identify periods in which an increased use of coercion was taking place and identify the causes. From the perspective of the Health Care Inspectorate, Argus data could identify institutions using a disproportionately high number of freedom restricting interventions, which could prompt more detailed investigation, and, for policy makers, the register could provide important information (GGZ Nederland 2012: 17).

\section{Achievements and controversies}

Undoubtedly, the aspirations of GGZ Nederland (2012: 26) for the Argus register were high:

By carrying out regular evaluations and referring back to Argus data, developments in the application of freedom restricting interventions will be made visible. It can be established how far the goal of policies and projects relating to freedom restricting interventions are being achieved. Furthermore, the evaluations and references to the data offer the possibility to learn from one's own practice: under which conditions does a health care provider tend to use a freedom restricting intervention? And can that intervention perhaps be different, less intrusive, shorter or more effective? These 
are important questions for health care providers who look critically at their own practice when it comes to freedom restricting interventions.

To some extent these goals were achieved. The Argus register has provided a dataset which researchers have been able to use to identify trends in the use of freedom restricting interventions, including restraint. This data has been used to map changes both within institutions in the Netherlands (Vruwink et al 2012; Janssen et al 2014; Verlinde et al 2014; Noorthoorn et al 2016), and to make comparisons between the use of coercion, seclusion and restraint in the Netherlands and other countries (Noorthoorn et al 2015; Lepping et al 2016). Janssen and colleagues have also discussed how to analyse and make comparisons at different levels using Argus data. They identify 'five different levels of calculation over several time frames', namely, hospital, ward, patients, admission and intervention (Janssen et al 2011: 431-32).

While documenting coercive incidents and analysing data is a quite common practice, it is relatively unusual to collect this data through a centralised agency, and for that data to be available for analysis by researchers (Lepping et al 2016: 1302). Relatively few such datasets exist worldwide (Lepping et al 2016: 1302), and the Argus register has allowed for benchmarking. This dataset has been used to monitor the use of seclusion, given the aforementioned target of reducing seclusion by 10 per cent on an annual basis (Noorthoorn et al 2016). Researchers have also recognised the importance of continuing to work with Argus (Voskes 2015: 176). These findings, and the factors which have been identified as influencing changing practice, are discussed further in the final section of this chapter.

However, problems with the registration of data have arisen from a perhaps unforeseen source: data protection legislation. While GGZ Nederland initially managed the Argus register, in 2016 this responsibility was transferred to the Stichting (or Foundation) Benchmark GGZ (SBG), which undertook this task on behalf of GGZ Nederland. This was intended to bring about a professionalisation of the data collection (GGZ Nederland 2016a). GGZ Nederland is an organisation of mental health care providers, while SBG was an independent expert centre managed by representatives of patients, health care providers and health insurers, which had the task of improving the quality of mental health care by improving transparency of treatment outcomes (GGZ Nederland 2016a).

GGZ Nederland felt that the management of the register by an independent organisation was important for benchmarking and policy development and would contribute to producing credible findings, data protection and further guarantee privacy (GGZ Nederland 2016a). In order to ensure this independence, the Argus Information Centre became a separate entity within SBG (GGZ Nederland 2016a). With regard to data protection, it was argued that information collected via Argus could not be linked to other information that was being collected by SBG and that privacy of individuals would be protected through a system whereby data was first submitted to a separate organisation (ZorgTTP (trusted third party)) 
which would then 'pseudonymise' ('gepsyeuonimiseren') the data before passing it on to SBG. This should have meant that the data could not be traced back to specific individuals (GGZ Nederland 2016a). In this way it was foreseen that legal requirements relating to data protection would be complied with. However, the data submitted to the ZorgTTP included personal data, including age, marital status, diagnosis and ward (Noorthoorn 2019). This meant that the information submitted could theoretically enable individual patients to be identified, especially in wards housing a small number of patients (Noorthoorn 2019), and this led to problems in the context of data protection.

At the end of 2016, GGZ Nederland wrote a letter to its members advising them to suspend temporarily the submission of data to the Argus Information Centre/SBG (GGZ Nederland 2016b). This followed a finding of the Dutch Data Protection Authority (2016) that 'pseudonymised' health data should be classified as personal data and fell under the Law on the Protection of Personal Data (acronym in Dutch: Wbp). This meant that the consent of patients was needed for this data to be submitted to the SBG. GGZ Nederland issued this advice to its members because, in light of the findings of the Data Protection Authority, there was no legal basis for the submission of 'pseudonymised' data, and the submission of the data could have adverse legal consequences for the organisations concerned. GGZ Nederland advised its members to stop submitting data until an exemption had been granted by the Authority or submission was legally regulated in another way. Members were however advised to continue collecting the data.

GGZ Nederland also separately advised its members to suspend the submission of data relating to Routine Outcome Monitoring (Healthcare - ICT Concerns [Zorg-ICT Zorgen] 2017a), which allowed for monitoring progress in mental health care and also involved 'pseudonymised' information concerning psychiatric treatment and results (GGZ Nederland 2017). This data was used for benchmarking and in making decisions regarding the purchase of health care by health insurers. In March 2017, the then Minister for Health, Welfare and Sport, Edith Schippers, answered a number of parliamentary questions relating to the collection of Routine Outcome Monitoring data, indicating that the Ministry was still investigating how to regulate its collection (House of Representatives of the Netherlands 2017a). In response to a second set of questions, the Minister indicated in October 2017 that 175 health care institutions had stopped submitting Routine Outcome Monitoring data (House of Representatives of the Netherlands 2017b). Elsewhere this was reported as meaning that only a third of mental health care institutions submitted data (Healthcare - ICT Concerns 2017b; van Lonkhuyzen 2017). In June 2017, it was announced that the Data Protection Authority was investigating SBG to see if the work which it did on behalf of the mental health sector complied with relevant data protection laws (van Lonkhuyzen: 2017), and whether Routine Outcome Monitoring data amounted to personal data under the Law on the Protection of Personal Data (House of Representatives of the Netherlands 2018). This investigation was welcomed by SBG, which indicated that it would be willing to change its procedures if necessary. 
In 2018 SBG ceased to function and was replaced by a new organisation, Akwa GGZ, which has the task of ensuring good quality mental health care, and works with patients, families and healthcare professionals. Akwa GGZ is an abbreviation of Alliantie Kwaliteit in de geestelijke gezondheidszorg (Alliance for Quality in Mental Health Care). Akwa GGZ took over the data collected by SBG, and, accordingly, the Data Protection Authority addressed its findings, when they finally came, to Akwa GGZ. Pending the publication of the Authority's report, the Secretary of State (a junior minister) for Health, Welfare and Sport advised health care providers to obtain the explicit consent of patients before submitting Routine Outcome Monitoring data (House of Representatives of the Netherlands 2018).

The Data Protection Authority finally published its report on the collection of Routine Outcome Monitoring data in the mental health sector in December 2019 (Dutch Data Protection Authority 2019). It concluded that the data received by SBG - including data related to Argus - involved the processing of personal data regarding health status which was prohibited under the European Union General Data Protection Regulation (Regulation (EU) 2016/679 of the European Parliament and of the Council (2016)) and was not covered by any of the exceptions provided for in the Regulation. As a result SBG, and now Akwa GGZ, was prohibited from processing this personal data regarding health status.

However, it seems that at least in the case of the Argus register, events superseded the investigation of the Data Protection Authority. As of October 2018, the Argus register was no longer in use and work is ongoing on the development of a new registration system in the Netherlands, which will comply with data protection legislation as well as meeting the requirements of the new mental health law, the Wvggz. Based on an interview conducted by this author with Dr Eric Noorthoorn (Noorthoorn 2019), it appears that the new register will record more forms of involuntary interventions, and interventions made at the request of the patient will not be registered. Under the new system hospitals will fully anonymise the data themselves, prior to submitting it, and there will be no possibility of an external party accessing information about individuals. Appropriate software, including business intelligence software, will be used by all institutions enabling them to submit tables containing the relevant information. The software will also allow for comparisons between institutions housing different kinds of patients, taking account of the fact that some institutions house individuals who are more likely to be subject to coercive interventions because of violent or aggressive behaviour. The submitted data can therefore still be used to identify trends in the use of coercion and make comparisons between institutions. It is anticipated that a number of institutions will begin testing the software and submitting data in 2020 , with the new register being fully operational, and in use by all covered institutions, by 2022. 


\section{Trends and developments in the use of coercive and involuntary measures in psychiatric institutions}

This section of the chapter identifies trends in the use of coercive measures in Dutch psychiatric institutions based on desk research. Much of the available research is based on data collected through the Argus register. In addition, again based on desk research, this section identifies the factors which seem to have influenced changes in the use of coercive measures, and particularly the use of seclusion in psychiatric institutions.

\section{A reduction in the use of seclusion}

As noted above, a goal of reducing seclusion in Dutch psychiatric hospitals by at least 10 per cent per year was established in 2006. Research has revealed that this goal was largely achieved, with an average annual reduction of seclusion of 9 per cent between 2008 and 2013, although some scholars have calculated slightly different figures (Voskes 2015: Ch 2; Noorthoorn et al 2015; Steinert, Noorthoorn and Mulder 2014: 4-5). Statistics reveal that the seclusion rate fell from 11.8 per cent in 2008 to 7.0 per cent in 2013 , and the median duration of seclusion decreased from 92 to 16 hours over the same period, although these findings are somewhat unreliable because a limited number of hospitals submitted Argus data in the first three years of the period covered by the study (Noorthoorn et al 2016: 1323). Research has also revealed that the reduction in seclusion was accompanied by an increase in the use of involuntary medication, suggesting that this coercive measure was partly used as a substitute for seclusion, although overall the total number of days on which coercive interventions took place decreased (Noorthorn et al 2016: 1323). In 2012, the then Minister of Health, Welfare and Sport, Edith Schippers, indicated that a reduction in seclusion could not lead to an increase in the use of forced medication (Verlinde et al 2014: 640). From a broader perspective, the number of involuntary admissions to mental health institutions under the Bopz increased between 2003 and 2013 quite significantly (Broer, Koetsier and Mulder 2014) and in 2017 there were a record number of committals to psychiatric hospitals (Kuiper 2018).

In spite of the aforementioned changes, seclusion remains more common in the Netherlands than in comparable countries, and seclusion times are also longer in the Netherlands (Noorthoorn et al 2015: 1857). An international study found 'much higher restraint and much higher seclusion numbers per admission, per patient and per capita in the Netherlands compared to other countries' (Lepping et al 2016: 1307). However, the study also found that other countries had higher uses of other forms of coercion, and 'in short, in some of the indicators some countries show higher figures than others, while the same countries show low figures on other indicators. In the end, the results were still much more similar than expected' (Lepping et al 2016: 1307). Nevertheless, from a Dutch perspective, research based on Argus data does reveal that the seclusion reduction programme had some success, and an 
overall reduction in the use of freedom restricting measures occurred in psychiatric institutions. It is therefore interesting to explore briefly what measures could have contributed to this change.

\section{Dutch interventions to reduce coercive and involuntary measures}

A very wide range of interventions have been used in Dutch mental health institutions in an attempt to reduce the use of coercion (Mann-Poll et al 2018: 734-46.; Vruwink et al 2012; Hamers et al 2013). Voskes (2015: 35) gives the following overview in her $\mathrm{PhD}$ dissertation:

These interventions can be grouped into five clusters: (1) care and contact, (2) prevention, (3) learning from experience, (4) participation, and (5) cooperation. Apart from new methods, structural and organisational innovations have been developed. Examples are comfort rooms, nurse stations behind accessible counters instead of in offices, and family rooms. Other structural innovations concern the adaptation of work plans and team meetings (for example, using risk assessment) and support activities (evaluation, feedback Argus data, and training). Finally, cultural changes have taken place.

It is beyond the scope of this chapter to examine the various coercion and seclusion reduction programmes which have been pursued. However, some general themes have emerged based on an analysis of the literature, and some of the themes identified in the Dutch literature correspond to the US National Technical Assistance Center's (2005) 'Six Core Strategies to Reduce the Use of Seclusion and Restraint' (Gooding et al 2018: 48-49). In general staffing and staff culture 'may be the most important factors [influencing] the use of coercive measures' (Janssen 2012). Duration of the coercion reduction programme seems to be of some importance, with research indicating that institutions which have been engaged in coercion and seclusion reduction efforts over a number of years achieve greater reductions and more stable reductions on average than institutions which have only recently initiated such measures (Voskes 2015: 43 and 165; Noorthoorn et al 2016: 1321-27).

A second theme is that new forms of intervention need to be accompanied by changes in organisational structure and culture, in order actually to lead to new practices, and that such changes require more time than that needed simply to introduce new forms of intervention (Voskes 2015: 43; Noorthoorn et al 2016: 1324-25). This implies a need for a change in 'ethical climate' (Voskes 2015: 162; Mann-Poll et al 2013) and having an ambitious project leader who has the backing of the organisation (Voskes 2015: 166). A change in culture should result in 'new views on the relationship with patients (from control to contact), the management of crisis (from reactive to proactive), the importance of learning from experience (from routine to learning), the role of participation (from object of care to partner 
in care), and the need for cooperation (from closed to open)' (Voskes 2015: 64-65). Cooperation between staff, and particularly psychiatrists and nursing staff and amongst nursing staff, also seems to be important in reducing coercion (Voskes, Theunissen and Widdershoven 2011: 41). Overall, 'in institutions in which top down and bottom up approaches are integrated, reduction of seclusion has more chance of being a success' (Voskes 2015: 166-67; Mann-Poll et al 2018: 741). Research also indicates that the successful introduction of a new policy requires 'the active involvement of all stakeholders, including patients' representatives and administrative leaders ... and nursing staff must be highly motivated, well-trained and sufficient in number' (Georgieva, Mudler and Noorthoorn 2013: 52). Changes to the infrastructure can enable or facilitate new approaches (Voskes 2015: 64), and cooperation with external partners, who can encourage reflection on 'takenfor-granted ideas and contribute new rationales and perspectives' (Voskes 2015: 167), are both important.

More controversially, some researchers have suggested that earlier use of (involuntary) medication can help to prevent seclusion and reduce the overall amount of coercive interventions. They also argue that, given the different nature of the two interventions (treatment versus management), involuntary medication cannot be regarded as substituting for seclusion (Verlinde et al 2014). However, other researchers have found that, while increased use of involuntary medication can reduce the number of seclusion incidents, it does not reduce the total number of involuntary interventions or the mean time spent in seclusion (Georgieva, Mudler and Noorthoorn 2013). As noted above, former Minister Schippers has also expressed opposition to 'substituting' seclusion with involuntary medication.

One initiative of interest is a compilation of best practices in the reduction of coercive treatment in mental health care facilities in the Netherlands (Voskes, Theunissen and Widdershoven 2011). This inventory was commissioned by the Ministry for Health, Welfare and Sport and GGZ Nederland, and was drawn up by three academics specialised in the field. They visited 26 institutions to identify and describe best practice, some of which was adopted as part of efforts to reduce the use of seclusion and other forms of coercion within the framework of the previously mentioned nationwide programme. The study also identified bottlenecks. All institutions which were visited had been engaged in a programme to reduce coercive measures for at least a year, and a variety of different kinds of departments and wards were visited. Best practices were identified in eleven categories: contact with the client, preventative work and risk assessment, de-escalation, evaluation, reflection, cooperation, client participation, participation of close relatives, registration, intensive care, and cooperation with ambulant care. Among the many examples listed, the Argus register was identified as best practice with regard to registration.

It has also been argued that it is important to measure the effects of programmes and measures aimed at reducing the use of coercion and seclusion, and that this can itself provide an incentive to improve programmes (Voskes 2015: 44). In this context, the Argus database can be regarded as an example of 'learning from experience' or 'measuring is knowing' 
('meten is weten'). 'Feedback from Argus data to involved departments and discussion with staff does not only help with understanding why an intervention was or was not effective, but motivates staff to improve the intervention and to continue working to reduce coercion' (Voskes, Theunissen and Widdershoven 2011: 43). However, research by Voskes revealed that while most institutions adequately registered coercive measures, feedback and evaluation of what the data revealed received less attention (Voskes 2015: 61; Voskes, Theunissen and Widdershoven 2011: 42). Whilst the data, when registered in a central database, can provide important evidence of overall trends, and allow for evaluations, it is important to also use it at an institution and ward level as part of an overall coercion reduction programme. Voskes argues 'registration of seclusion data (as a working routine) has only added value by providing structural feedback and a shared belief that the data are useful for learning' (Voskes 2015: 65). Janssen has similarly argued that 'the reported coercive measures must be embedded in a larger organisational context in which the data are used in feedback to provide information for evaluation purposes, treatment planning as well as ward and hospital policy' (Janssen 2012). Therefore, simply accurately recording data on the use and duration of coercive practices, time consuming though that is, will have no impact on reducing these practices unless it is used with this purpose in mind.

\section{Conclusion}

This chapter has provided an overview of the regulation of the use of restraint, seclusion and other forms of coercion in the Dutch mental health, psychogeriatric and intellectual disability care sectors. It has also reported on initiatives which have been taken to reduce coercion, with a particular focus on the registration of freedom-restricting incidents in a national database, the Argus register. The register was seen as a necessary tool to monitor national efforts to reduce the use of seclusion in psychiatric institutions in particular, and it allowed for benchmarking and comparisons across institutions and hospital wards in the Netherlands and internationally. However, Argus data collection has faced a perhaps unexpected challenge from data protection legislation, and this has resulted in a suspension of reporting and plans to develop a new registration system. The chapter has also revealed that while such data collection allows for benchmarking and can be a part of policy to reduce seclusion, restraint and other coercive measures within individual institutions, a conscious effort must be made to use locally collected data in this way.

\section{References}

Arends, L.A.P. (2004) 'Legal Status of Incompetent Patients in Psychogeriatric Settings from a Dutch Perspective', Medicine and Law, 23(4): 821-31.

Arends, L.A.P. (2015) 'Not with a Single Comb. Psychogeriatrics, Mental Health Care and Psychiatry Need their Own Frameworks' ['Niet over één kam, Psychogeriatrie, verstandelijk 
genhandicaptenzorg en psychiatrie hebben hun eigen kaders nodig'], Journal of Health Law [Tijdschrift voor Gezondheidsrecht], 39(4): 221-25.

Arends, L.A.P. (2010) 'Report on the Autumn Meeting of the VGR 2009 "Compulsion and Freedom Restrictions in Health Care", ['Verslag najaarsvergadering VGR 2009 "Dwang en vrijheidsbeperkingen in de zorg"'], Journal of Health Law [Tijdschrift voor Gezondheidsrecht], 2 April: 94-104.

Blankman, K. and Vermariën, V. (2015) Conformity of the UN Convention on the Rights of Persons with Disabilities with Current and Proposed Legislation on Representation of Mentally Incompetent Persons [Conformiteit van het VN-Verdrag inzake de rechten van personen met een handicap met de huidige en voorgestelde wetgeving inzake vertegenwoordiging van wilsonbekwame personen], Report commissioned for Netherlands Human Rights Institute, Amsterdam: Vrije Universiteit Amsterdam.

Bopz Decision Means and Measures [Besluit middelen en maatregelen Bopz] (1993) Available https://wetten.overheid.nl/BWBR0006225/1994-01-17 (accessed 20 June 2020).

Broer, J., Koetsier, H. and Mulder, C.L. (2014) 'Increasing Use of Coercive Treatment under the Bopz Act; Implications for the New Compulsory Mental Health Care Act' ['Stijgende trend in dwangtoepassing onder de Wet Bopz; implicaties voor de nieuwe Wet verplichte geestelijke gezondheidszorg'], Journal of Psychiatry [Tijdschrift voor Psychiatrie], 57(4): 240-47.

Care and Compulsion (Psychogeriatric and Intellectually Disabled Patients) Act [Wet Zorg en Dwang] (Wzd). Available https://www.dwangindezorg.nl/wzd/wet--en-regelgeving-zorgen-dwang (accessed 20 June 2020).

Compulsory Mental Health Care Act [Wet verplichte geestelijke gezondheidszorg] (Wvggz) (2018). Available https://www.dwangindezorg.nl/uitvoering/documenten/publicaties/informatiepunt/documente n/1/wet-verplichte-ggz (accessed 20 June 2020).

Dutch Association of Psychiatry (2008) Guideline Decision-Making and Coercion in Mental Health Care [Richtlijn Besluitvorming dwang en drang in de GGZ], Available https://www.nvvp.net/stream/richtlijn-besluitvorming-dwang-opname-en-behandeling2008.pdf (accessed 20 June 2020). 
Dutch Data Protection Authority [Autoriteit Persoonsgegevens] (2016) Letter to The Dutch Health Care Authority [Brief aan de Nederlandse Zorgautoriteit]. Available

https://autoriteitpersoonsgegevens.nl/sites/default/files/01_onderzoek_nza-dis.pdf (accessed 20 June 2020).

Dutch Data Protection Authority [Autoriteit Persoonsgegevens] (2019) Report Resulting from a Research into Data Processing by SBG [Rapport naar aanleiding van onderzoek gegevensverwerking $S B G]$. Available https://autoriteitpersoonsgegevens.nl/sites/default/files/atoms/files/rapport_bevindingen_sbg_ en_akwa_ggz.pdf (accessed 20 June 2020).

Frederiks, B.J.M. (2015) 'Progressive Insight, Forced Care in Psychogeriatrics and Mental Disability Care in One Legal Regulation with Psychiatry' ['Voortschrijdend inzicht, Gedwongen zorg in psychogeriatrie en verstandelijk gehandicaptenzorg in één wettelijke regeling met psychiatrie'], Journal of Health Law [Tijdschrift voor Gezondheidsrecht], 39(4): 226-31.

Frederiks, B.J.M. and Blankman, K. (2013) 'Proposed Law on Care and Coercion: Impact of Recent Changes for the Field and the Client' ['Wetvoorstel Zorg en dwang: impact van de recente wijzingen voor het veld en de cliënt'], Journal of Health Law [Tijdschrift voor Gezondheidsrecht], 37(4): 346-61.

Frederiks, B.J.M. and Steen, S.M. (2018) 'The Care and Compulsion Act is Adopted, and Now? ['De Wet zorg en dwang is aangenomen, en nu?'], Journal of Health Law [Tijdschrift voor Gezondheidsrecht], 42(2): 156-63.

Georgieva, I., Mulder, C.L. and Noorthoorn, E.O. (2013) 'Reducing Seclusion through Involuntary Medication: A Randomized Clinical Trial', Psychiatry Research 2015(1-2): 4853.

GGZ Centraal (2019) Costs of Involuntary Care [kosten onvrijvillige zorg]. Available https://www.ggzcentraal.nl/clienten/kosten/kosten-onvrijwillige-zorg/ (accessed 20 June 2020).

GGZ Nederland (2017) Delivering ROM Data [Aanlevering Rom-Gegevens]. Available https://www.ggznederland.nl/actueel/aanlevering-rom-gegevens (accessed 20 June 2020). 
GGZ Nederland (2016a) Background Information on Locating the Argus Information Centre (AIC) with the Stichting Benchmark GGZ (SBG) [Achtergrondinformatie bij het onderbrengen van het Argus Informatie Centrum (AIC) bij de stichting benchmark ggz $(S B G)$ ], Amersfoort: GGZ Nederland (on file with author).

GGZ Nederland (2016b) Letter of 9 November 2016 from GGZ Nederland, Subject: Temporary Stopping of Submission of Data to the Argus Information Centre [Subject: Tijdelijk stoppen aanlevering aan Argus Informativecentrum], Amersfoort: GGZ Nederland (on file with author).

GGZ Nederland (2012) Argus: Registration of Freedom-restricting Interventions in Mental Health Care [Argus: Registratie van vrijheidsbeperkende interventies in de geestelijke gezondheidszorg]. Available https://www.ggznederland.nl/uploads/publication/Argus\%20Registratie\%20van\%20vrijheids beperkende\%20interventies\%20in\%20de\%20ggz.pdf (accessed 20 June 2020).

Gooding, P., McSherry, B., Roper, C. and Grey F. (2018) Alternatives to Coercion in Mental Health Settings: A Literature Review, Melbourne: Melbourne Social Equity Institute, University of Melbourne. Available https://socialequity.unimelb.edu.au/news/latest/alternatives-to-coercion (accessed 20 June 2020).

Hamers, J.P.H., Gulpers, M.J.M., Bleiglevens, M.H.C., Capezuti, E. and van Rossum, E. (2013) 'A Dutch Roadmap for Care Without Belt Usage' ['De weg naar een bandenloze zorg in Nederland'], Journal of Gerontology and Geriatrics [Tijdschrift voor Gerontologie en Geriatrie], 44(6): 253-60.

Health Care Inspectorate [Inspectie voor de Gezondsheidszorg] (2015) Mental Health Care Institutions Investing in Reducing Seclusion; Further Actions are Needed to Achieve Ambitions [GGZ-instelling investeren in terugdringen van separatie; verdere acties nodig om ambities te halen]. Available https://zoek.officielebekendmakingen.nl/blg-525986.pdf (accessed 20 June 2020).

Health Care Inspectorate [Inspectie voor de Gezondsheidszorg] (2016) Health Care Inspectorate Multi-year Plan 2016-2019 [IGZ Meerjarenbeleidsplan 2016-2019], Available https://www.igj.nl/documenten/jaarplannen/2016/01/14/igz-meerjarenbeleidsplan-2016-2019 (accessed 20 June 2020). 
Healthcare - ICT Concerns [Zorg-ICT Zorgen] (2017a) General Audit Chamber Makes Mince of ROM in Curative Mental Health Financing [Algemene Rekenkamer maakt gehakt van ROM in curatieve GGZ-financiering]. Available https://www.zorgictzorgen.nl/algemenerekenkamer-maakt-gehakt-rom-curatieve-ggz/ (accessed 20 June 2020).

Healthcare - ICT Concerns [Zorg-ICT Zorgen] (2017b) Secretary of State Assumes Giving of Explicit Permission when Continuing to Deliver ROM Data [Staatssecretaris veronderstelt geven van expliciete toestemming bij doorgaan leveren ROM-data]. Available https://www.zorgictzorgen.nl/staatssecretaris-veronderstelt-geven-expliciete-toestemmingdoorgaan-leveren-rom-data/ (accessed 20 June 2020).

House of Representatives of the Netherlands [Tweede Kamer der Staten-Generaal] Aanhangsel Handelingen 2016/17 1477 (2017a) Response from Minister Schippers (24 March 2017) Appendix to Proceedings, 2016-2017 session year [Antwoord van Minister Schippers (24 March 2017). Aanhangsel Handelingen, vergaderjaar 2016-2017]. Available https://zoek.officielebekendmakingen.nl/ah-tk-20162017-1477.html (accessed 20 June 2020).

House of Representatives of the Netherlands [Tweede Kamer der Staten-Generaal] Aanhangsel Handelingen 2017/18 218, (2017b) Response from Minister Schippers to Questions Submitted by Members of Parliament Kooiman and Dieterns about the Necessity of a Study on the Coercion of Patients to Fill in ROM Lists (submitted 8 September 2017) [Vragen van de leden Kooiman (SP) en Diertens (D66) aan de Minister van Volksgezondheid, Welzijn en Sport over de noodzaak van een onderzoek naar de dwang bij patiënten om ROM-lijsten in te vullen (ingezonden 8 september 2017)]. Available https://zoek.officielebekendmakingen.nl/ah-tk-20172018-218.pdf (accessed 20 June 2020).

House of Representatives of the Netherlands [Tweede Kamer der Staten-Generaal] Aanhangsel Handelingen 2017/18 1780 (2018) Answer from Secretary of State Blokhuis (16 April 2018) Appendix to Proceedings, 2017-2018 session year [Antwoord van Secretary of State Blokhuis (16 April 2018) Aanhangsel Handelingen, vergaderjaar 2017-2018]. Available https://zoek.officielebekendmakingen.nl/ah-tk-20172018-1780.html (accessed 20 June 2020).

Hout, F.A.G., Nienhuis, E.D., Robben, P.B., Frederiks, B.J. and Legemaate, J. (2010) 'Supervision by the Dutch Healthcare Inspectorate', European Journal of Health Law, 17(4): 347-60. 
Hubben, J.H. (2012) 'The Health Care Inspectorate: from Silent Power to Public Watchdog' ['De IGZ: van stille kracht naar publieke waakhond'], Journal of Health Law [Tijdschrift voor Gezondheidsrecht], 2: 96-108.

Janssen, W.A. (2012) Argus: Assessment and Use of Data Evaluating Coercive Measures in Dutch Psychiatry, Unpublished PhD. thesis, Vrij Universiteit, Amsterdam. Available: https://research.vu.nl/en/publications/argus-assessment-and-use-of-data-in-evaluatingcoercive-measures- (accessed 20 June 2020).

Janssen, W., Noorthoorn, E.O., van de Sande, R., Nijman, H., Smit, A., Hoogendoorn, A., Voskes, Y., Mulder, N. and Widdershoven, G. (2014) 'Six Years of Argus, Freedomrestricting Interventions in Mental Health Care in 2012 and Developments Compared to Previous Years' ['Zes jaar Argus, Vrijheidsbeperkende interventies in de GGz in 2012 en ontwikkelingen ten opzichte van voorgaande jaren']. Available https://www.ggznederland.nl/uploads/assets/Rapport\%20\%20zes\%20jaar\%20argus\%2017062014.pdf.pdf (accessed 20 June 2020).

Janssen, W.A., van de Sande, R., Noorthoorn, E.O., Nijman, H.L., Bowers, L., Mulder, C.L., Smit, A., Widdershoven, G.A. and Steinert, T. (2011) 'Methodological Issues in Monitoring the Use of Coercive Measures', International Journal of Law and Psychiatry, 34(6): 429-38.

Ketelaars, C.A.J. (2011) 'Integrated Care Requires Integrated Supervision', International Journal of Integrated Care, 11: 1-6.

Kuiper, M. (2018) 'Record of Forced Admissions' ['Record aan gedwongen opnames'], NRC Today, 28 February. Available https://www.nrc.nl/nieuws/2018/02/28/record-aangedwongen-opnames-2-a1593877 (accessed 20 June 2020).

Legemaate, J. (2001) 'The Quality Control of the Health Care Inspectorate (IGZ)' ['Het toezicht van de Inspectie voor de Gezondheidszorg (IGZ) op de kwaliteit van de zorg'], Journal of Health Law [Tijdschrift voor Gezondheidsrecht], 25: 139-48.

Lepping, P., Masood, B., Flammer, E. and Noorthoorn, E.O. (2016) 'Comparison of Restraint Data from Four Countries', Social Psychiatry and Psychiatric Epidemiology, 51(9): 1301-09. 
Mann-Poll, P.S., Smit, A., Noorthoorn, E.O., Janssen, W.A., Koekkoek, B. and Hutschemaekers, G.J.M. (2018) 'Long-Term Impact of a Tailored Seclusion Reduction Program: Evidence for Change?', Psychiatric Quarterly, 89(3): 733-46.

Mann-Poll P.S., Smit, A., van Doeselaar, M. and Hutschemaekers, G.J. (2013) 'Professionals' Attitudes After a Seclusion Reduction Program: Anything Changed?', Psychiatric Quarterly, 84(1): 1-10.

Netherlands National Health Care Institute [Zorginstituut Nederland] (2019) Mental Health Care in an Institution Falling under the Long-term Care Act [GGZ in een Wlz-instelling $(W l z)$ ]. Available https://www.zorginstituutnederland.nl/Verzekerde+zorg/g/ggz-in-een-wlzinstelling (accessed 20 June 2020).

Netherlands National Health Care Institute [Zorginstituut Nederland] (2017) Care and Support for People with a Mental Health Condition [Zorg en ondersteuningvoor mensen met een psychische aandoening]. Available https://www.zorginstituutnederland.nl/Verzekerde+zorg/g/ggz-in-een-wlzinstelling/documenten/brochure/2017/08/16/zorg-en-ondersteuning-voor-mensen-met-eenpsychische-aandoening (accessed 20 June 2020).

Netherlands Ministry of Health, Welfare and Sport [Ministrie van Volksgezondheid, Welzijn en Sport] (2016) The Dutch Healthcare System [Het Nederlandse Zorgstelsel]. Available https://www.rijksoverheid.nl/documenten/brochures/2016/02/09/het-nederlandse-zorgstelsel (accessed 20 June 2020).

Noorthoorn, E.O. (2019) Telephone interview with author, 1 May.

Noorthoorn, E.O., Lepping, P., Janssen, W., Hoogendoorn, A., Nijman, H., Widdershoven, G. and Steinert, T. (2015) 'One-year Incidence and Prevalence of Seclusion: Dutch Findings in an International Perspective', Social Psychiatry and Psychiatric Epidemiology, 50: 185769.

Noorthoorn, E.O., Voskes, Y., Janssen, W.A., Mulder, C.L., van de Sande, R., Nijman, H.L., Smit, A., Hoogendoorn, A.W., Bousardt, A. (2016) 'Seclusion Reduction in Dutch Mental Health Care: Did Hospitals Meet Goals', Psychiatric Services, 67(12): 1321-27. 
Organisation for Economic Co-Operation and Development (2019) Health Expenditure and Financing. Available https://stats.oecd.org/Index.aspx?DataSetCode=SHA (accessed 20 June 2020).

Ploem, M.C. and Gevers, J.K.M. (2015) 'Legislation in Psychiatry, Psychogeriatrics and Mental Disability Care, Better Half Turned than Completely Lost' ['Wetgeving in de psychiatrie, psychogeriatrie en verstandelijk gehandicaptenzorg, Beter ten halve gekeerd dan ten hele gedwaald'], Journal of Health Law [Tijdschrift voor Gezondheidsrecht], 39(4): 20311 .

Pols, J. (2002) 'Enforcing Patient Rights or Improving Care? The Interference of Two Modes of Doing Good in Mental Health Care', Sociology of Health and Illness, 25(4): 320-47.

Psychiatric Hospitals (Committals) Act [Wet bijzondere opnemingen in psychiatrische ziekenhuizen] (Bopz) (1992). Available https://wetten.overheid.nl/BWBR0005700/2018-0801 (accessed 20 June 2020).

Public Health Act [Gezondheidswet] (1956). Available https://wetten.overheid.nl/BWBR0002202/2019-02-01 (accessed 20 June 2020).

Regulation (EU) 2016/679 of the European Parliament and of the Council of 27 April 2016 on the Protection of Natural Persons with Regard to the Processing of Personal Data and on the Free Movement of Such Data, and Repealing Directive 95/46/EC (General Data Protection Regulation (2016) OJ L 119/1.

Robbe, P.N.M., Bal, R. and Grol, R.P.T.M. (2012) 'Public Sector Supervision by the Health care Inspectorate' ['Overheidstoezicht door de Inspectie voor de Gezondheidszorg'], WRR Web Publication [WRR Webpublicatie], 62.

Steinert, T., Noorthoorn, E.O. and Mulder C.L. (2014) 'The Use of Coercive Interventions in Mental Health Care in Germany and the Netherlands. A Comparison of the Developments in Two Neighboring Countries', Frontiers in Public Health, 2(141): 1-10.

van Lonkhuzen, L. (2017) 'Privacy in Mental Health Care at Issue' ['Privacy in geestelijke zorg in geding'], NRC Today, 13 July. Available https://www.nrc.nl/nieuws/2017/07/13/privacy-in-geestelijke-zorg-in-geding-12018987a1566633 (accessed 20 June 2020). 
Verlinde, A.A., Snelleman, W., van den Berg, H. and Noorthoorn, E.O. (2014) 'Effect of Compulsory Medication as an Untervention of First Choice on Separation and Applied Coercion; A Prospective Cohort Study' ['Effect van dwangmedicate als interventie van eerste keus op separatie en toegepaste dwang; een prospectief cohortonderzoek'], Journal of Psychiatry [Tijdschrift voor Psychiatrie], 56(10): 640-48.

Voskes, Y. (2015) No effect without ethics, Reduction of Seclusion in Psychiatry from a Care Ethics Perspective, Unpublished PhD. Thesis, Vrije Universiteit Amsterdam. Available: https://research.vu.nl/en/publications/no-effect-without-ethics-reduction-of-seclusion-inpsychiatry-fro (accessed 20 June 2020).

Voskes, R., Theunissen, J. and Widdershoven, G. (2011) Best Practics around Reducing Coercion in Mental Health Care [Best Practices rondom dwangreductie in de geestelijke gezondheidszorg], Amsterdam: Vrije Universiteit Amsterdam. Available http://vnverdragwaarmaken.nl/vnverdragwaarmaken/images/wetzorgendwang/best-practicesrondom-dwangreductie-in-de-geestelijke-gezondheidszorg.pdf (accessed 20 June 2020).

Vruwink, F.J., Mulder, C.L., Noorthoorn, E.O., Uitenbroek, D. and Nijman, H.L.I. (2012) 'The Effects of a Nationwide Program to Reduce Seclusion in the Netherlands', BMC Psychiatry, 12:231: 1-4.

Welie, S.P.K. and Widdershoven, T.P. (2018), 'CRPD and Forced Psychiatry: How to Proceed?' ['VPH and dwangpsychiatrie: hoe verder?'], Journal of Health Law [Tijdschrift voor Gezondheidsrecht], 42(1): 6-22.

World Health Organization (2019) European Health Information Gateway. Available https://gateway.euro.who.int/en/ (accessed 20 June 2020). 